\title{
Interaction between the canopy dwelling echinoid Holopneustes purpurescens and its host kelp Ecklonia radiata
}

\author{
Peter D. Steinberg* \\ School of Biological Science, University of Sydney, Sydney, New South Wales 2006, Australia
}

\begin{abstract}
I examined the interaction between the unusual, canopy dwelling echinoid Holopneustes purpurescens and its main host plant, the kelp Ecklonia radiata. During a 4 yr study at Cape Banks, New South Wales, Australia, $H$. purpurescens reached densities as high as 1 ind. per thallus of $E$. radiata and $>17 \mathrm{~m}^{-2}$, with densities declining strongly in the latter years of the study. These sea urchins also occurred, although at lower densities, on the dictyotalean alga Homoeostrichus sinclaini. H. purpurescens consumed laminae of E. radiata in the field at the rate of $\sim 1 \mathrm{~g}$ large ind. ${ }^{-1}$ (diameter $>40 \mathrm{~mm}$ ) $\mathrm{d}^{-1}$ Consumption by the sea urchins was not affected by variation in phlorotannin levels among laminae. The impact of feeding by $H$. purpurescens on E. radiata, measured as (1) changes in the biomass of the kelps and (2) changes in thallus elongation rates, was examined in field experiments done in 2 seasons in which different numbers and sizes of sea urchins were caged with individual E. radiata. In spring, all densities and sizes of $H$. purpurescens caused significant damage (biomass) to E. radiata after 4 wk, and higher densities (2 per kelp thallus) of large sea urchins resulted in kelp mortality. No measurable damage occurred in autumn, with all kelps losing large amounts of biomass. No significant effect on thallus elongation rates was seen in either season after 4 wk. However, elongation rates varied among treatments after $2 \mathrm{wk}$ in autumn. Grazing by $H$. purpurescens did not result in compensatory growth by E. radiata, nor did levels of phlorotannins in the kelps increase in response to grazing (chemical induction)
\end{abstract}

KEY WORDS: Holopneustes purpurescens - Herbivory Kelp - Echinoids - Mesograzers - Inducible defenses

\section{INTRODUCTION}

Marine herbivores have a major impact on populations and communities of benthic macroalgae (Lubchenco \& Gaines 1981, Hawkins \& Hartnoll 1983, John et al. 1992). In temperate sublittoral algal communities, probably the most ecologically important plant/herbivore interaction occurs between regular echinoids, or sea urchins, and brown algae in the Orders Laminariales (kelps) and Fucales. The extensive literature on the effects of sea urchins in temperate kelp or fucoid forests (reviews by Lawrence 1975, Lawrence \& Sam-

- Present address: School of Biological Science, University of New South Wales, Sydney, New South Wales 2052, Australia. E-mail-p.steinberg@unsw.edu.au marco 1982, Harrold \& Pearse 1987, Andrew 1988) has repeatedly shown that grazing by sea urchins can completely change the physical and biological structure of these algal communities. In extreme cases sea urchins can denude the substratum of extensive areas of kelp, creating so-called 'barren' or (more properly) 'deforested' areas which then become dominated by encrusting coralline and small turfing algae (Lawrence 1975, Schiel \& Foster 1986, Harrold \& Pearse 1987. Andrew 1988). The striking dichotomy in habitat types represented by kelp forests vs deforested areas has prompted some authors (e.g. Harrold \& Pearse 1987) to consider sea urchins as 'all or nothing' herbivores. That is, they either eliminate most large macroalgae from the habitat or have relatively little effect, surviving primarily on drift algae (Harrold \& Reed 1985, Andrew \& Stocker 1986). 
Contrasting with sea urchins - and a variety of other large marine grazers such as fishes or some gastropods - is the taxonomically diverse group of marine herbivores known as 'mesograzers' or 'mesoherbivores' (Fauchald \& Jumars 1979, Hay et al. 1987. Brawley 1992, Hay 1992). These smaller herbivores ( $1 \mathrm{~mm}$ to $2 \mathrm{~cm}$ in size), which include amphipods, crabs, other arthropods, polychaetes and small gastropods such as ascoglossans, have a number of features which distinguish them from larger herbivorous sea urchins. Firstly, mesograzers typically live within an alga, using it as habitat as well as food (Hacker \& Steneck 1990, Duffy \& Hay 1991a, Brawley 1992). Secondly, mesograzers rarely denude substrata of established stands of macroalgae, and in general the effects of mesograzers on macroalgae are thought to be much weaker (Carpenter 1986, Hay \& Steinberg 1992) than the effects of larger herbivores such as sea urchins (although see Brawley 1992, Poore 1994). Thirdly, although feeding specialization is rare among marine herbivores (Hay 1992, Hay \& Steinberg 1992), those marine specialists which do exist are frequently mesograzers. Herbivorous sea urchins, in contrast, are typically very generalist feeders (Lawrence 1975, Harrold $\&$ Pearse 1987). Fourthly, mesograzers are often resistant or tolerant to algal secondary metabolites which deter feeding or inhibit growth of large generalist herbivores such as sea urchins or fishes (Hay et al. 1987, Hay 1992, Hay \& Steinberg 1992)

In this paper I examine aspects of the ecology of an unusual herbivorous sea urchin, Holopneustes purpurescens (Family Temnopleuridae), that exhibits characteristics of both mesograzers and more typical herbivorous sea urchins. Although comparable in size (test diameter $\geq 50 \mathrm{~mm}$ ) to many other sea urchins which live and forage directly on the sea floor, $H$. purpurescens lives largely or exclusively off the substratum, enmeshed in the fronds of seaweeds such as the kelp Ecklonia radiata (Dakin 1980). Because of its use of seaweeds as habitat as well as food, its interaction with its macroalgal hosts is likely to be quite different from that of other sea urchins. Here I explore 5 aspects of the interaction between $H$. purpurescens and its major host plant, E. radiata. Firstly, I ask: What is the distribution and abundance of $H$. purpurescens in and around E. radiata forests? Secondly: At what rate does $H$. purpurescens consume E. radiata? Thirdly, because both algal dwelling mesograzers (Hay \& Steinberg 1992) and large invertebrate herbivores in Australia (Steinberg \& van Altena 1992) are often resistant to algal chemical defenses, I ask: Is consumption of $E$. radiata by $H$. purpurescens affected by variation in phlorotannin content - the major secondary metabolite of E. radiata - of the kelps? Fourthly, I examine the impact of $H$. purpurescens herbivory on E. radiata.
Finally, I investigate whether $E$. radiata responds to damage caused by $\mathrm{H}$. purpurescens via either (1) compensatory growth or (2) induction of elevated levels of phlorotannins.

\section{MATERIALS AND METHODS}

Abundance, size distribution, and occurrence of Holopneustes purpurescens on host plants. This study was done in sublittoral habitats at the Cape Banks Marine Research Reserve near Sydney, New South Wales, Australia (described in Fletcher 1987, Andrew 1993) between 1986 and 1990 (except for 1 short-term feeding experiment done in 1993). This area is comprised of a mosaic of forests of the kelp Ecklonia radiata interspersed with deforested areas covered in encrusting coralline or small turfing algae.

The abundance of Holopneustes purpurescens in and around forests of Ecklonia radiata was measured in 2 ways. Firstly, in 1986 and 1987 a preliminary survey was done by marking out a $5 \times 5 \mathrm{~m}$ grid in a forest of $E$. radiata (designated as Forest 2) at $6 \mathrm{~m}$ depth at Cape Banks. Within this large quadrat 100 large (stage 3 of Kirkman 1984) E. radiata were randomly selected, tagged with. Dymo tape and cable ties, and the number and sizes of $H$. purpurescens on these 100 plants measured in October and December 1986 and March 1987 Secondly, in April (autumn) 1988, a monitoring program was begun in which sizes and densities of $H$. purpurescens were measured in 3 kelp forests (designated Forests 1, 2, and 3) approximately seasonally for $2 \frac{1}{2} \mathrm{yr}$ until autumn 1990 (monitoring in Forest 3 was begun in winter 1988). These kelp forests were at 5 to $7 \mathrm{~m}$ depth at Cape Banks, with Forest 1 the most inshore and protected and Forest 3 the most seaward and exposed. At each kelp forest at each sampling time, a grid was established using $30 \mathrm{~m}$ transect tapes and twelve $0.25 \mathrm{~m}^{2}$ quadrats placed randomly within the forest. In each quadrat all large (stage 3) E. radiata were counted, each kelp and all understory algae searched for $H$. purpurescens, and the number and size of $H$. purpurescens in each plant (kelp or otherwise) noted. Sizes of $H$. purpurescens were measured as the maximum oral-aboral diameter, as these sea urchins tend to elongate along the oral-aboral axis as they get large (pers. obs.).

Beginning in winter 1988 , beds of the dictyotalean algae Homoeostrichus sinclairii, which occurred in nearly monospecific patches on the margins of these Ecklonia radiata forests, were also sampled for Holopneustes purpurescens. At each sampling time for each kelp bed, twelve $0.25 \mathrm{~m}^{2}$ quadrats with at least $75 \%$ cover of $H$. sinclairii were searched for $H$. purpurescens. Numbers and sizes of $H$. purpurescens were measured as above. 
Consumption of Ecklonia radiata by Holopneustes purpurescens. Gut contents of $10 \mathrm{H}$. purpurescens collected from E. radiata in October 1986 contained obvious fragments of $E$. radiata. In order to estimate consumption rates of $H$. purpurescens when eating kelp, and to determine preferences by the sea urchins for different parts of the kelp, 3 consumption experiments were done. In the first experiment, 22 large (oral-aboral diameter $>40 \mathrm{~mm}$ ) $H$. purpurescens were individually caged in plastic prawn crates bolted to the substratum at $4 \mathrm{~m}$ depth (Steinberg \& van Altena 1992). Each individual was fed 1 piece each of preweighed (to $0.1 \mathrm{~g}$ ) secondary and primary laminae of $E$. radiata, each massing $\sim 15 \mathrm{~g}$. Five pieces of laminae were individually caged without sea urchins to control for autogenic tissue loss. After $4 \mathrm{~d}$ the algae were removed from all cages and reweighed. In addition, prior to adding the pieces of E. radiata to the cages, samples of approximately $1 \mathrm{~g}$ were removed from each laminae. These samples were brought back to the laboratory, extracted in aqueous methanol, and their phlorotannin content measured using the Folin-Denis assay (Ragan \& Jensen 1977. Steinberg 1989).

In the second and third experiments, one done in 1989 and one in 1993, 21 large Holopneustes purpurescens were caged with individual pieces of secondary laminae, each massing $\sim 20 \mathrm{~g}$. Controls for autogenic losses were run concurrently as above. The algae were removed from the cages after 5 (1989) or 6 (1993) days and reweighed. Between 2 and 4 individuals died or developed abraded patches on their tests in each experiment, and data from these cages were excluded from subsequent analyses. Phlorotannin levels of the laminae were measured at the start of the experiment as above.

Effects of Holopneustes purpurescens on Ecklonia radiata. The effects of $H$. purpurescens on $E$. radiata were assessed by varying the numbers and sizes of $H$. purpurescens enclosed within plastic cages surrounding individual kelp plants. Cages consisted of flexible plastic garden fencing with a mesh size of $20 \mathrm{~mm}$. The fencing was formed into tubes approximately $0.5 \mathrm{~m}$ in diameter using plastic cable ties, and placed around each kelp. The tube cages were attached to the substratum using eye bolts bolted into the rock, with the tops of the cages extending 25 to $30 \mathrm{~cm}$ above the distal tip of the enclosed kelp. The cages moved with the current to some extent, minimizing abrasion on the kelp.

These sea urchin/kelp enclosure experiments were carried out in Forest 1 (5 m depth) on 2 occasions, autumn/early winter (April to July, henceforth designated 'autumn'), and late winter/spring (August to November, designated 'spring') 1988. Each experiment lasted for $\sim 14 \mathrm{wk}$. Treatments in the experiments consisted initially of uncaged kelp plants (Controls), and individual plants caged with either 0,1 medium $(1 \mathrm{M}), 1$ large $(1 \mathrm{~L}), 2$ medium $(2 \mathrm{M})$, or 2 large $(2 \mathrm{~L}$; spring only) sea urchins (as described below under 'Responses of Ecklonia radiata to herbivory', some treatments were modified $4 \mathrm{wk}$ into each experiment by removal of sea urchins from some cages). There were 5 kelp per treatment. Size classes of the sea urchins were arbitrarily defined as medium, with oralaboral diameters 28 to $40 \mathrm{~mm}$, and large, with oralaboral diameters $>40 \mathrm{~mm}$.

Effects of the sea urchins on the kelp were determined by measuring changes in (1) biomass and (2) elongation of the individual plants. Changes in biomass were measured as follows: prior to caging, each plant was carefully chipped off the substratum at the base of the holdfast. The holdfast was then attached to a triangular piece of stiff plastic mesh (mesh size $5 \mathrm{~mm}$ ) using cable ties. Three dynabolts were fixed into the substratum, spaced to accommodate the plastic mesh, and the plastic mesh, with attached plant, was then attached to the bolts using stainless steel wingnuts. The assembly was then placed back in the plant's original position. The entire procedure was done underwater.

This setup allowed the plants to be removed from the water, weighed, and returned to their position/cage. On Day 0 of each experiment (autumn and spring) plants were removed from the water in groups of 4 to 5 , quickly weighed to the nearest $1 \mathrm{~g}$ on a portable top loading balance, and placed back in position within their cages. The kelp were kept wet as long as possible during this procedure, with excess water removed by shaking the plants just prior to weighing. When all plants had been weighed, the appropriate number and size of Holopneustes purpurescens were placed on each caged plant. Plants were weighed again after $2,4,8$ and $14 \mathrm{wk}$ in the autumn experiment, and 2, 4,9 and $13.5 \mathrm{wk}$ in the spring experiment. This technique both enabled accurate measurements of the change in mass of the plants and, importantly, allowed changes in biomass and elongation rates (below) to be scaled to the initial size of the plants (since presumably the initial size of the plants will have a significant effect on growth). Measuring changes in biomass in this fashion incorporates positive changes due to growth of the plants and loss of tissue due to herbivory, sloughing, etc.

Elongation of the plants was measured by a standard technique for measuring growth in kelp, in which holes are punched in the primary laminae above the intercalary meristematic region and movement of the holes towards the distal end of the plant monitored (Mann 1972, Mann \& Kirkman 1981).

Responses of Ecklonia radiata to herbivory. Does damage by Holopneustes purpurescens stimulate compensatory growth in E. radiata? In order to inves- 
tigate the extent to which $E$, radiata recovers from grazing by $H$. purpurescens and whether grazing stimulates an increase in growth by the kelps, responses of the kelps following grazing were examined in both the autumn and spring enclosure experiments. In autumn, all sea urchins were removed from caged plants $4 \mathrm{wk}$ after the start of the experiment. Plants were weighed 4 and $10 \mathrm{wk}$ later $(8$ and $14 \mathrm{wk}$ into the experiment, respectively) so as to compare differences in growth among treatments after the removal of sea urchins.

In spring, after $4 \mathrm{wk}$ of the experiment, sea urchins were removed from 3 of the 5 plants in each treatment containing sea urchins, leaving urchins on the remaining 2 plants in each treatment. This generated 'sea urchin removed' and 'sea urchin remaining' treatments, with $\mathrm{n}=3$ or 2 (respectively) kelps per treat- ment. The new treatments were designated as '-' or ' + ' for each relevant combination of size and density of $H$. purpurescens. Thus (for example) 2M- indicates a cage from which the 2 medium sea urchins in the cage were removed after $4 \mathrm{wk}, 2 \mathrm{M}+$ a cage in which the sea urchins were left in place. Plants in spring were weighed again at 9 and 13.5 wk into the experiment (5 and 9.5 wk after urchin removal).

Does grazing by Holopneustes purpurescens induce elevated levels of phlorotannins in Ecklonia radiata? Phlorotannin content of the E. radiata in the sea urchin/kelp enclosure experiments was measured at the beginning of the experiment and again after $4 \mathrm{wk}$ in order to test for induction of phlorotannins due to grazing. This was done by removing approximately $1 \mathrm{~g}$ of tissue from a secondary lamina midway up each plant and subsequently analyzing phlorotannin con-

A.

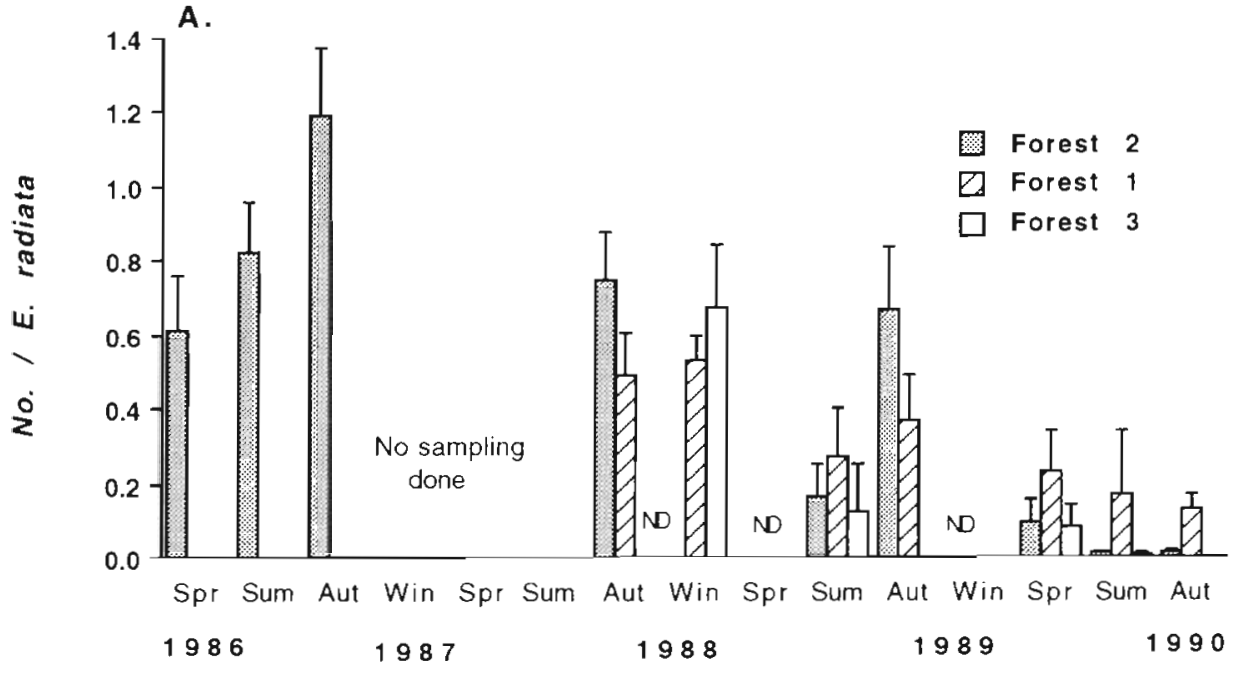

B.

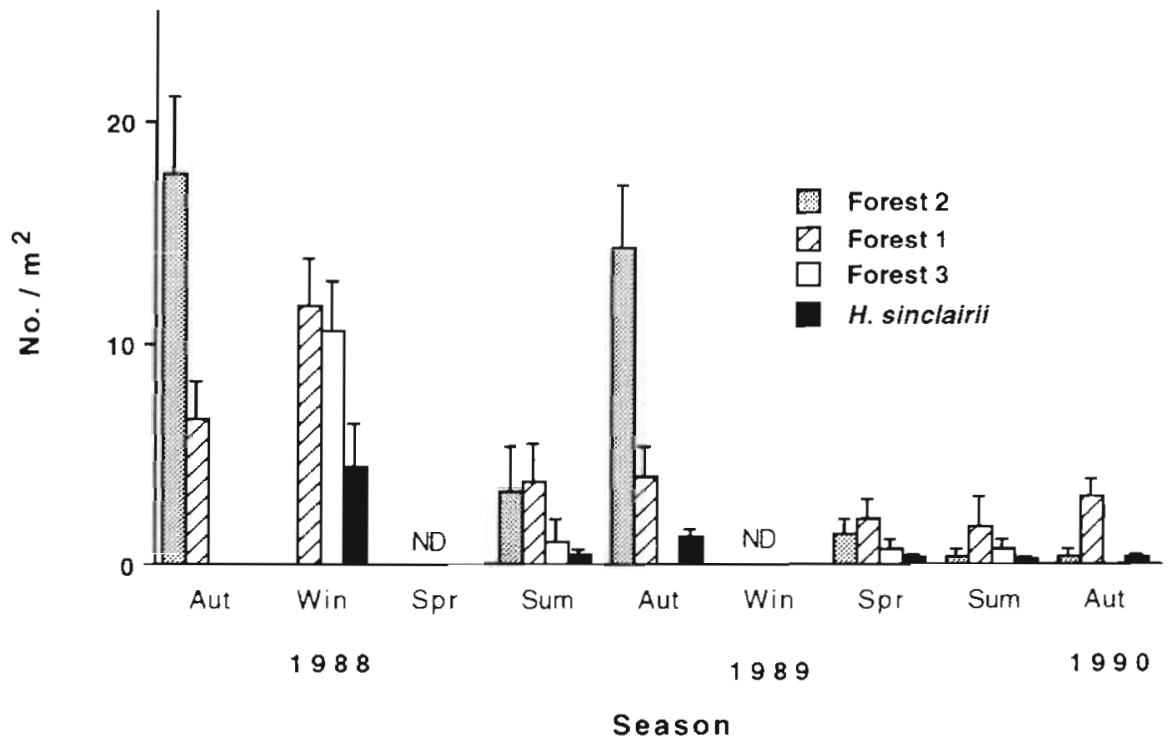

Fig. 1 Holopneustes purpurescens. Number of urchins (A) per Ecklonia radiata and (B) per $\mathrm{m}^{2}$ in 3 kelp forests at Cape Banks, New South Wales, Australia, from 1986 to 1990. Data given as means + SE. Data for abundance on Homoeostrichus sinclairii combined for all forests at each season. ND: no data collected for a given season (in 1988, no data were collected for Forest 3 in autumn, nor for Forest 2 in winter). No H. purpurescens were found in Forest 3 during autumn 1989 and 1990. Note that data collection began in (A) 1986 and (B) 1988 
tent using the Folin-Denis technique as described above. As removal of up to $25 \%$ of the mass of E. radiata by artificial means (clipping the laminae) has no significant effect on phlorotannin levels (Steinberg 1994), I assumed that clipping $1 \mathrm{~g}$ of tissue from plants which weigh $>200 \mathrm{~g}$ would have little effect on the plants. Measurement of phlorotannins consistently from a specified part of the thallus is important as the

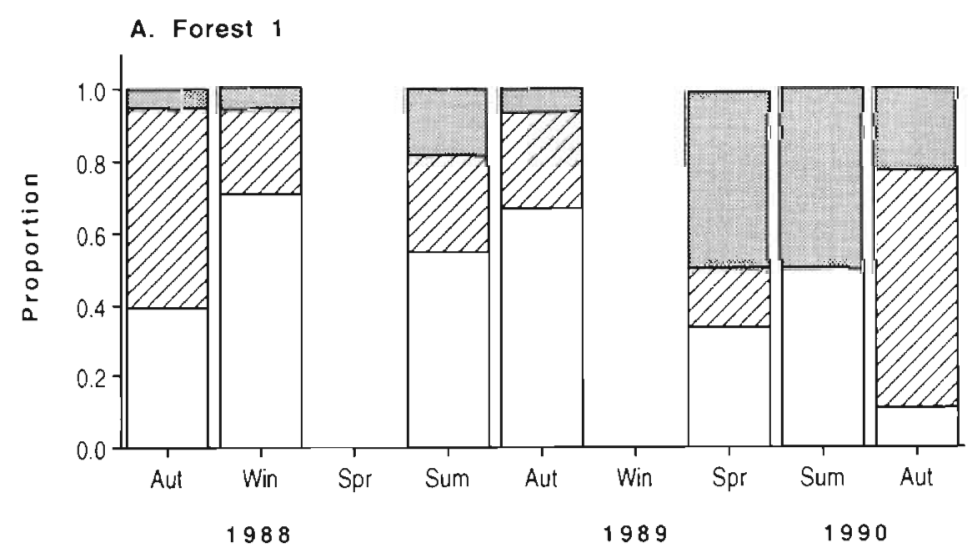

B. Forest 2

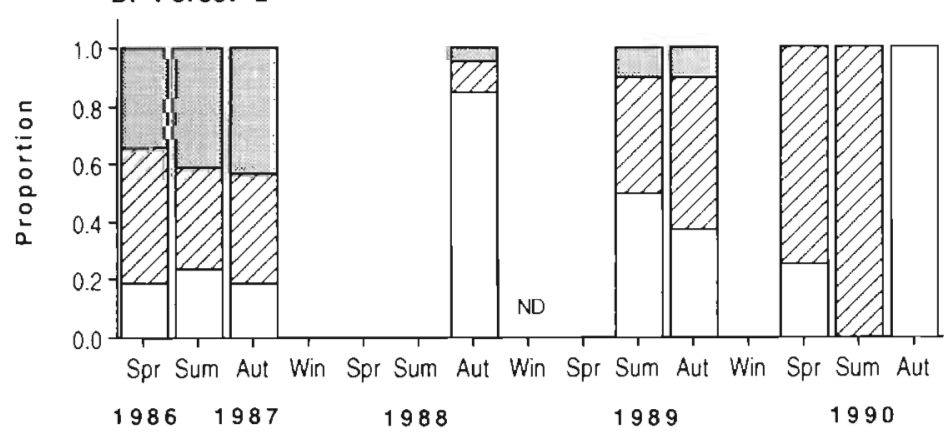

c. Forest 3

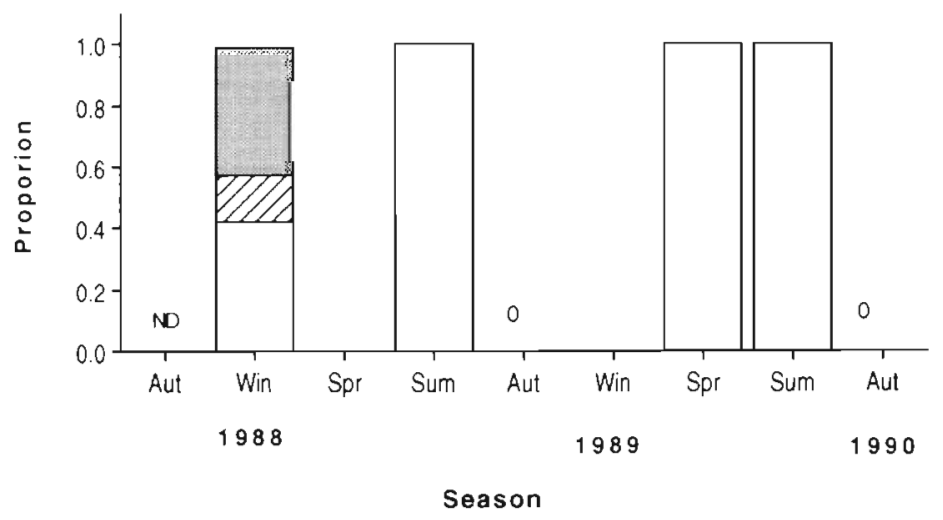

Fig. 2. Holopneustes purpurescens. Proportion of each of 3 size classes in 3 kelp forests at Cape Banks from 1988 to 1990 (1986 to 1990 for Forest 2). Data from all quadrats at each forest at each time have been combined. Size classes are large (oral-aboral diameter $>40 \mathrm{~mm}$; shaded bars), medium (diameter 28 to $40 \mathrm{~mm}$; striped bars) and small (diameter $<28 \mathrm{~mm}$; open bars). 0 : no urchins found at that forest at that time phlorotannin content varies significantly among different parts of the thallus (Steinberg 1989). Secondary laminae were used because $H$. purpurescens primarily consumes secondary laminae and phlorotannin levels in $E$. radiata are highest in this part of the thallus (Steinberg 1989, Andrew \& Jones 1990).

By analyzing phlorotannin content at the beginning of the experiment and after $4 \mathrm{wk}$, changes in phlorotannin content in individual kelps could be calculated. To test for induction of phlorotannins, changes in phlorotannin levels of the kelp were compared among treatments after $4 \mathrm{wk}$, and were also regressed against changes in biomass over the same period.

\section{RESULTS}

\section{Abundance of Holopneustes purpurescens in and around Ecklonia radiata forests}

Maximum mean densities of Holopneustes purpurescens at Cape Banks during the study were $1.16 \pm 0.22$ (SE) per Ecklonia radiata plant (Fig. $1 \mathrm{~A}$ ) and $17.6 \pm 3.1 \mathrm{~m}^{-2}$ (Fig. 1B). The maximum number of sea urchins observed on a single plant during the study was 6 . In 1986 to 1988 , densities of $>0.5$ sea urchins per plant and $>10$ individuals $\mathrm{m}^{-2}$ were common. In the latter years of the study (1989 to 1990), the abundance of Holopneustes substantially declined, with densities typically below 0.4 plant $^{-1}$ and $3 \mathrm{~m}^{-2}$. No $H$. purpurescens were found at Forest 3 on several sampling occasions in 1989 and 1990. Densities of $H$. purpurescens currently remain low at these sites at Cape Banks (pers. obs., summer 1994). All H. purpurescens sampled in the kelp beds were found on E. radiata with the exception of a single individual enmeshed in the understory alga Sargassum vestitum. No H. purpurescens were found on the substratum.

Size distributions for Holopneustes purpurescens are shown in Fig. 2, with urchin sizes arbitrarily divided into 3 categories: small (0 to $28 \mathrm{~mm}$ oral-aboral diameter), medium (28 to $40 \mathrm{~mm}$ diameter), and large (>40 mm). Large and medium urchins were common at all sites in the early years of the study (Fig. 2), but the average size of $H$. purpurescens decreased substantially in 1989 and 1990, particularly at Forests 2 and 3 (Fig. 2). No large urchins were found in the last several samples at these sites. 
Holopneustes purpurescens also occurred in beds of Homoeostrichus sinclairii on the margins of the forests of Ecklonia radiata. However, both densities (Fig. 1B) and mean sizes (Fig. 3) of the sea urchins were typically much less in beds of $H$. sinclairii than in the adjacent kelp forests. Except for the winter sample of 1988, densities of $H$. purpurescens in beds of $H$. sinclairii beds were always $<1.2 \mathrm{~m}^{-2}$. This winter 1988 sample contained an unusually large number of sea urchins on $H$. sinclairii at Forest 3 and also contained all the large (>40 mm) $H$. purpurescens urchins found on $H$. sinclairii during the study.

\section{Consumption of laminae of Ecklonia radiata by Holopneustes purpurescens and its correlation with phlorotannin content}

In field consumption experiments, Holopneustes purpurescens consumed an average of $\sim 1.0 \mathrm{~g}$ of Ecklonia radiata $\mathrm{d}^{-1}$ and consumed secondary laminae $\left(\right.$ mean \pm SE consumption $\left.=0.74 \pm 0.21 \mathrm{~g} \mathrm{~d}^{-1}\right)$ preferentially to primary laminae $\left(0.23 \pm 0.14 \mathrm{~g} \mathrm{~d}^{-1}\right)$. The mean consumption of secondary laminae was significantly greater, as determined by a paired $t$-test ( $\mathrm{df}=18, t=$ 3.90, $\mathrm{p}<0.001$ ). Variation in phlorotannins among pieces of laminae was not correlated with variation in consumption, neither for consumption of secondary laminae (phlorotannin content $=6.54 \pm 0.87 \%$ dry mass) vs primary laminae (phlorotannin content $=1.82$ $\pm 0.35 \%$ ) nor for consumption of different secondary laminae which varied in phlorotannin content (Fig. 4A, B) between 3 and $9 \%$ dry mass.

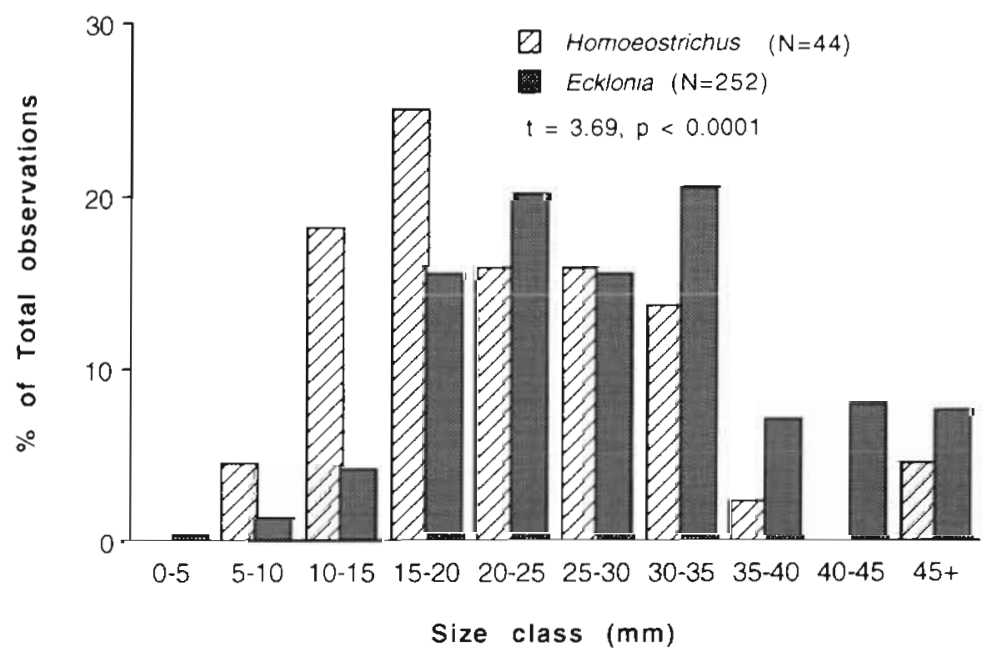

Fig 3. Holopneustes purpurescens. Size frequency distributions in Ecklonia radiata forests and frnging beds of Homeostruchus sinclaurii. Data from all forests and sampling dates from 1988 through 1990 have been combined
A.

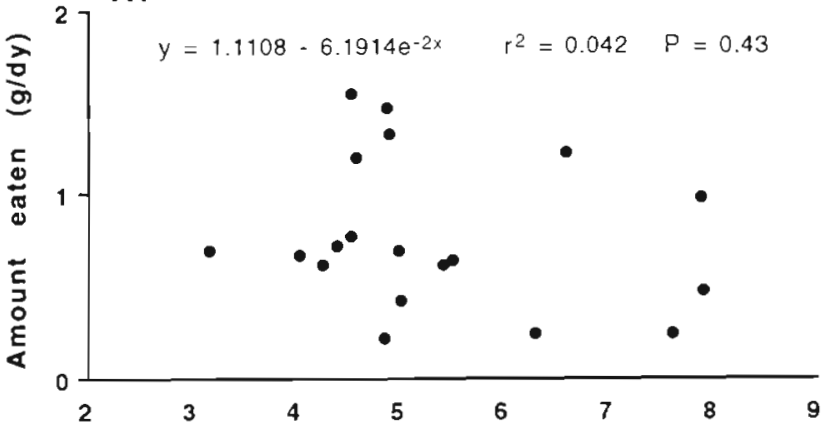

B.

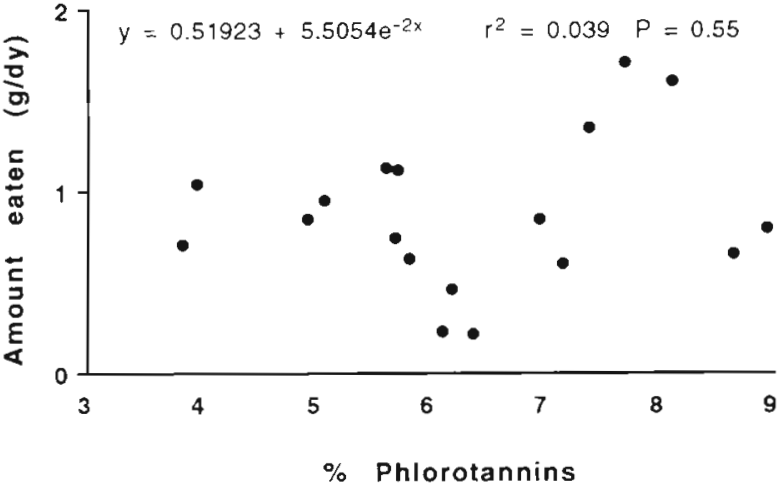

Fig. 4. Holopneustes purpurescens. Consumption of individual secondary laminae of Ecklonia radiata vs phlorotannin content of the laminae. Results of regression analyses are shown for 2 separate experiments, (A) 1989 and (B) 1993. Neither regression has a slope significantly different from zero

\section{Effects of Holopneustes purpurescens on Ecklonia radiata}

The effects of Holopneustes purpurescens on changes in biomass of Ecklonia radiata varied strongly with size density, length of time of the sea urchins on the kelp, and with season. In autumn, there was no effect of $H$. purpurescens on $E$. radiata, with plants in all treatments losing substantial 125 to $40 \%$ of initial size) amounts of biomass after 4 wk (Fig. 5A, B).

In spring, however, the sea urchins caused substantial damage to the kelps (Fig. 5C, D). The amount of damage caused by the urchins varied predictably, with increases in the size, density, or length of time of Holopneustes purpurescens on the plants reducing biomass in an additive fashion (Fig. 5C, D). After $4 \mathrm{wk}$, grazing by 2 (medium or large) $H$. purpurescens had removed all the new 

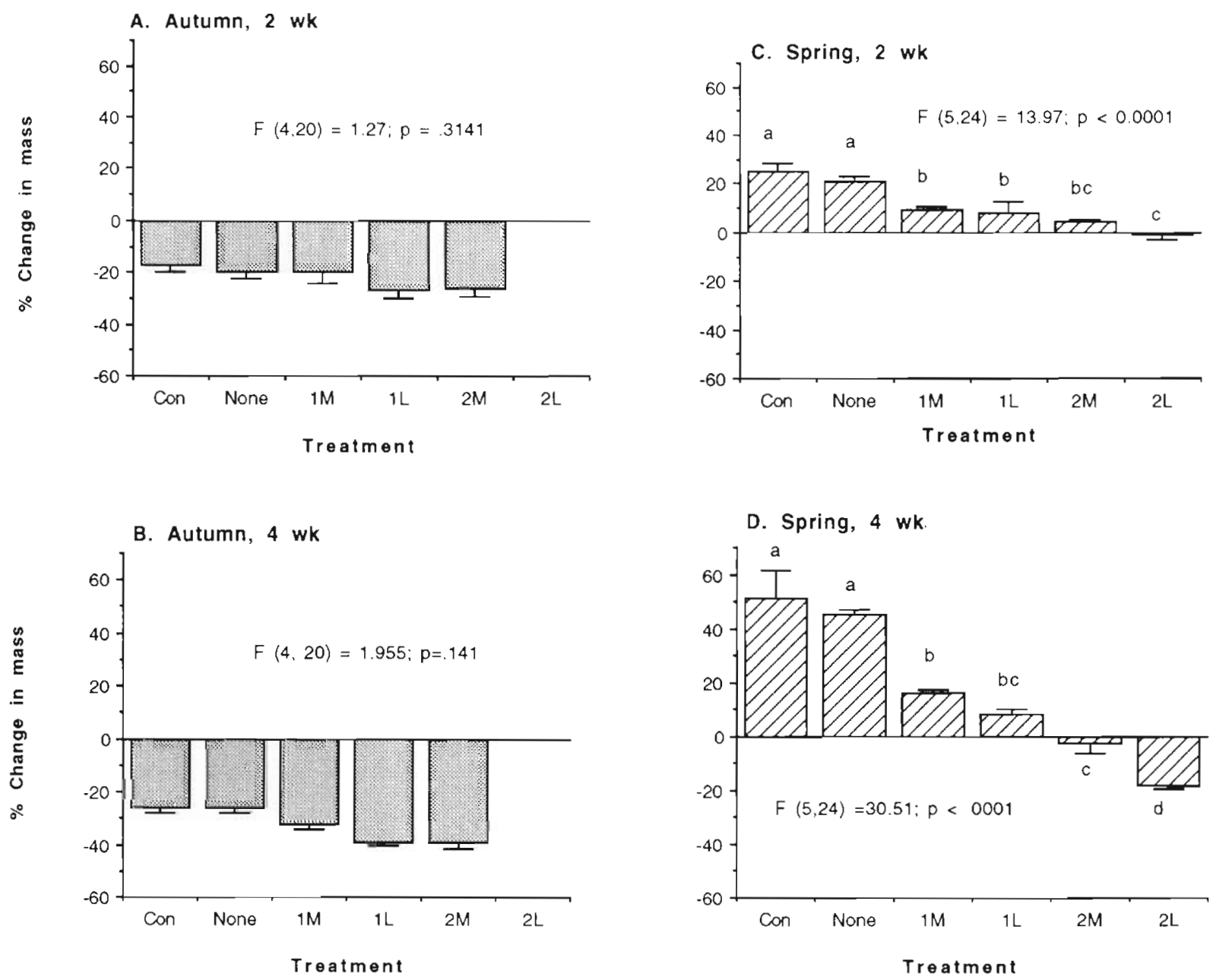

D. Spring, 4 wk

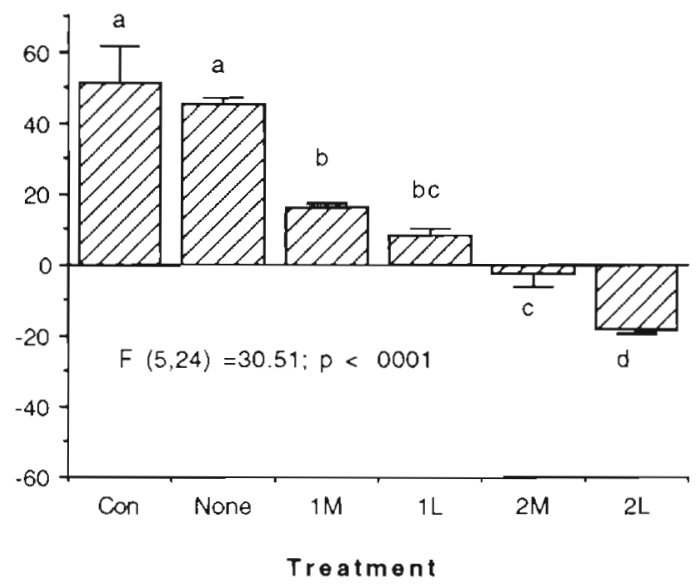

Fig. 5. Ecklonia radiata. Change in biomass of kelps caged with different sizes (M: medium; L: large) and densities (None, 1, or 2) of Holopneustes purpurescens. Con: control plants lacking cages or sea urchins. Data given as mean + SE of percent change in mass (relative to the initial mass of each plant). Analyses for each time/season are single factor ANOVAs on $\ln (x+1)$ of the proportional change in mass, followed by Tukey's simultaneous multiple range test (where the ANOVA was significant). Means sharing a letter are not significantly different. $\mathrm{n}=5$. Autumn experiment after (A) 2 and (B) 4 wk. Spring experiment after

(C) 2 and (D) $4 \mathrm{wk}$. The 2L treatment was not done in the autumn

production of the enclosed plants, resulting in a net weight loss (Fig. 5D). One plant in the 2L treatment developed a large hole in the meristematic region after 2 wk, apparently due to the feeding behavior of $H$. purpurescens, and ultimately died $(6 \mathrm{wk}$ into the experiment; an additional plant in this treatment died after $8 \mathrm{wk}$ ). However, in most instances, primary laminae and meristems of the kelps were undamaged, indicating that the sea urchins mostly consumed secondary laminae.

In contrast to the effects on kelp biomass, Holopneustes purpurescens had no effect on elongation of Ecklonia radiata after $4 \mathrm{wk}$ in either season (Fig. 6). There was statistically significant variation (ANOVA, $p=0.036$ ) in rates of elongation among treatments in autumn after $2 \mathrm{wk}$ (Fig. 6A), but the pattern of varia- tion was not consistent with any simple effect of the sea urchins on the kelps.

\section{Longer-term effects and compensatory growth}

In autumn, removal of all Holopneustes purpurescens from the cages after $4 \mathrm{wk}$ did not result in a significant increase in biomass of the Ecklonia radiata plants over the subsequent $10 \mathrm{wk}$ (Fig. 7 ; paired $t$-test between plant sizes at Week 4 vs Week 14 for all plants was not significant), nor were there differences in biomass among treatments at Week 14 (ANOVA). Comparison of the final masses of the autumnal plants and the mean initial mass of the plants in the spring experiment also indicated that little growth of the kelp had 

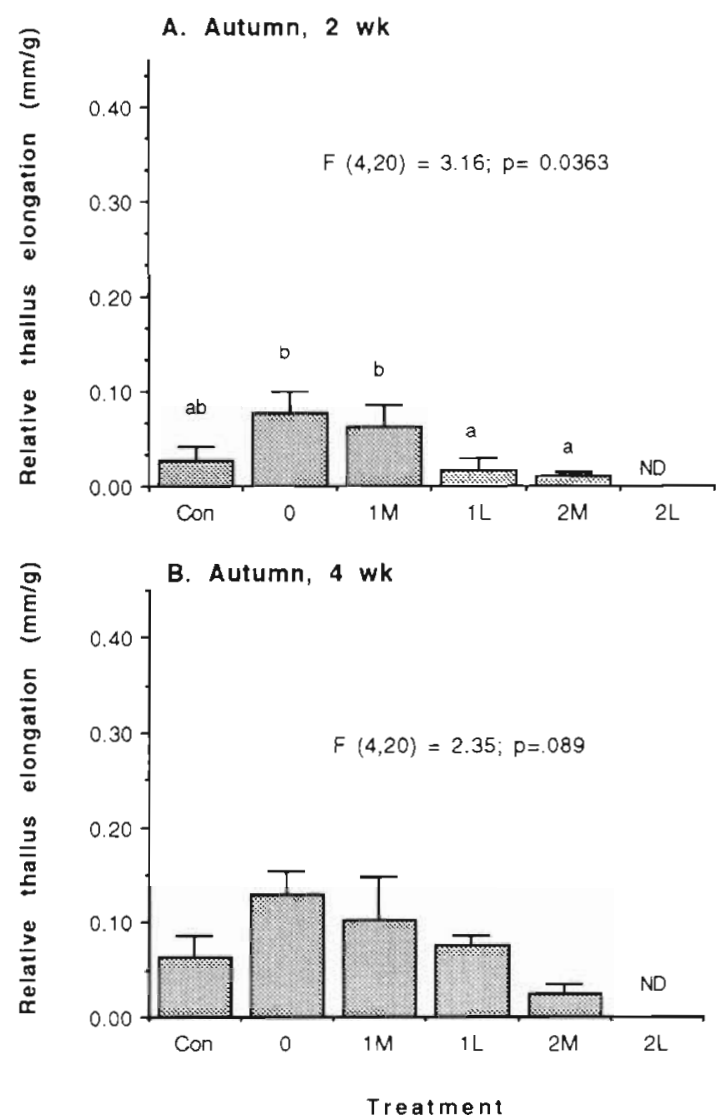

C. Spring, 2 wk

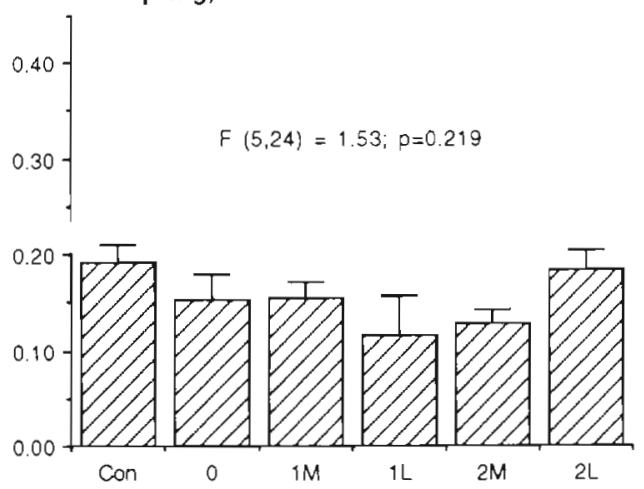

D. Spring, 4 wk

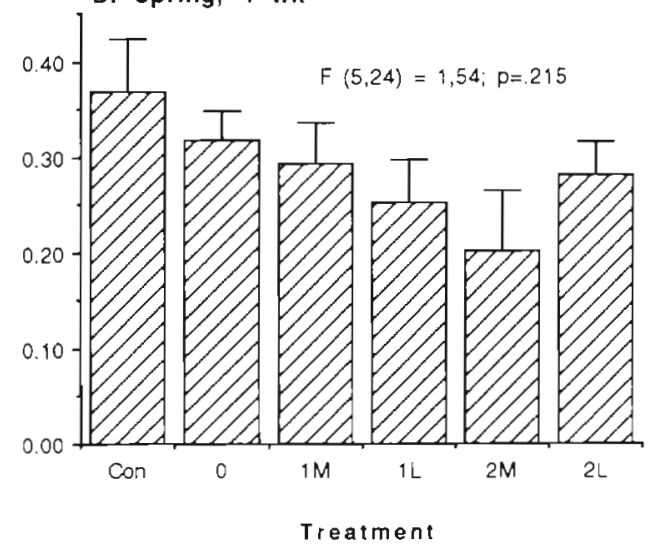

Fig. 6. Ecklonia radiata. Elongation of plants caged with different sizes and densities (as per Fig. 5) of Holopneustes purpurescens. Data given as mean + SE of mass specific elongation rates (total length elongated in a given period scaled to the plant's initial mass). Analyses are single factor ANOVA on $\ln (x+1)$ transformed data, followed by Tukey's test where appropriate. $\mathrm{n}=5$. Elongation after (A) 2 and (B) $4 \mathrm{wk}$ in autumn and after (C) 2 and (D) 4 wk in spring
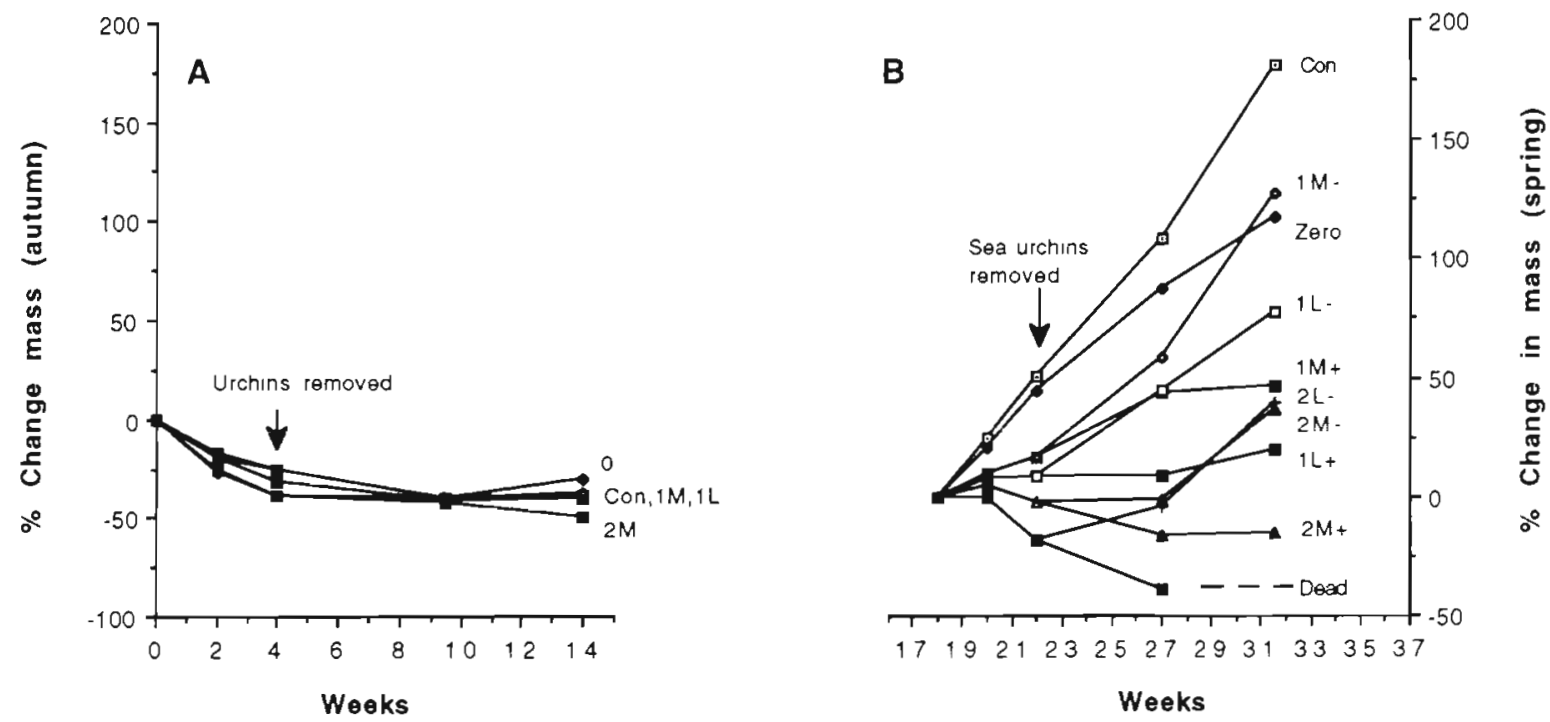

Fig. 7. Ecklonia radiata. Percent change in biomass for plants in (A) autumn and (B) spring caging experiments for the entire course of these experiments. Data are means per treatment, $\mathrm{n}=2$ to 5 (see 'Materials and methods'). Error bars omitted for clarity. Treatments indicate the number of urchins per kelp $(0,1$ or 2$)$, their sizes ( $S$ : small; $M$ : medium; L: large) and whether, after $4 \mathrm{wk}$ in the spring experiment, sea urchins were removed or left on the plants $(-,+$ respectively). $X$-axis: number of weeks since the start of the autumn experiment 
occurred in the $4 \mathrm{wk}$ period between the 2 experiments.

In spring, however, 4 wk of herbivory by Holopneustes purpurescens had long-term effects on Ecklonia radiata, even when the sea urchins were removed from the plants (Fig. 7). This conclusion is based on a comparison of the proportional change in biomass among treatments after 9 and 13.5 wk in the spring experiment (single-factor ANOVA followed by SNK tests), with treatments in the experiment now consisting of (a) the original Zero and Control, (b) 'urchin removed' (e.g. 1M-, 1L-, 2M-, 2L-), and (c) 'urchin remaining' $(1 \mathrm{M}+, 1 \mathrm{~L}+, 2 \mathrm{M}+, 2 \mathrm{~L}+)$ treatments. Because these divided treatments resulted in small sample sizes ( $\mathrm{n}=2$ to 3 per treatment), differences were assessed using SNK tests with $\alpha$ set at both 0.05 and 0.10 . After $9 \mathrm{wk}$, the treatments differed significantly (Fig. 7; single-factor ANOVA, $F_{8,19}=9.17, \mathrm{p}<$ 0.001 ; the $2 L+$ treatment was excluded from the analy-

A.

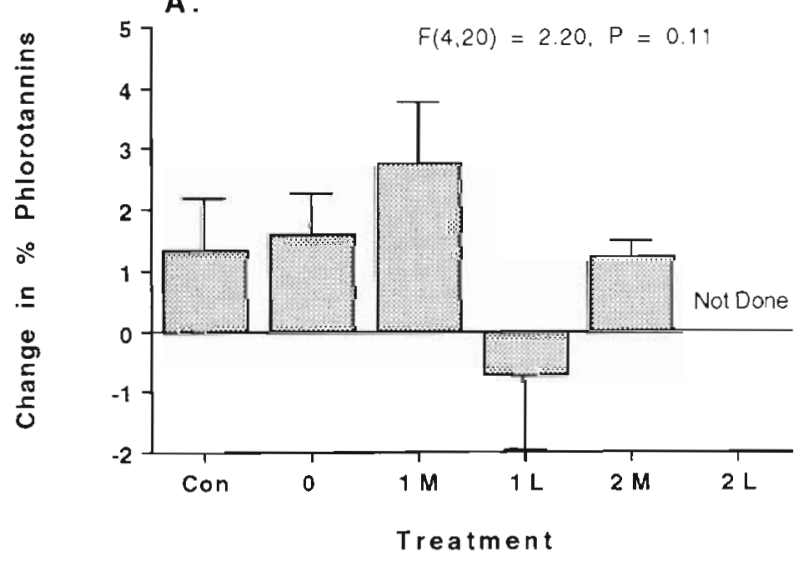

B.

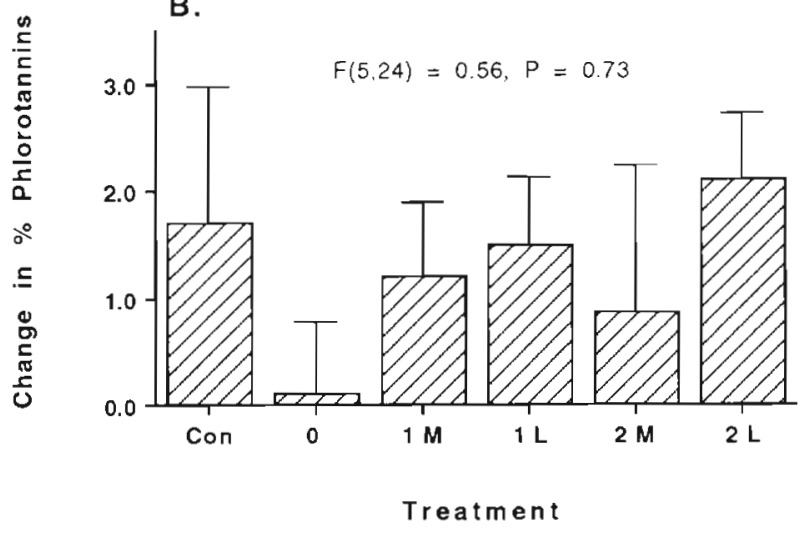

Fig. 8. Ecklonia radiata. Change in \% phlorotannins by dry mass after $4 \mathrm{wk}$ (calculated as phlorotannin levels after $4 \mathrm{wk}$ initial levels) for plants in various treatments in the (A) autumn and (B) spring Holopneustes purpurescens enclosure experiments. Data given as mean $+\mathrm{SE}, \mathrm{n}=5$. Statistical results from single-factor ANOVA sis as only 1 plant survived to $9 \mathrm{wk}$ in this treatment) with change in biomass of the plants in the Control and Zero treatments greater than that in the $2 \mathrm{M}-, 2 \mathrm{~L}-$, and $2 M+$ treatments at $\alpha=0.05$ and greater than that in the $1 \mathrm{~L}+, 1 \mathrm{M}+, 2 \mathrm{M}-, 2 \mathrm{~L}-, 2 \mathrm{M}+$, and $1 \mathrm{~L}$ - treatments at $\alpha=$ 0.10 . After $13.5 \mathrm{wk}\left(\mathrm{F}_{7,15}=9.176, \mathrm{p}=0.0002 ; 2 \mathrm{~L}+\right.$ and $1 \mathrm{M}+$ treatments now excluded because of 0 and 1 plant remaining, respectively) the Control and Zero treatments differed significantly (SNK tests) from the $1 \mathrm{~L}+$ and $2 M+$ treatments at $\alpha=0.05$ and differed significantly from the $2 \mathrm{~L}-, 2 \mathrm{M}-, 1 \mathrm{~L}-, 1 \mathrm{~L}+$, and $2 \mathrm{M}+$ treatments at $\alpha=0.10$. These results indicate that $E$. radiata subjected to short bursts ( $4 \mathrm{wk}$ ) of grazing by $H$. purpurescens in the spring did not in general 'catch up' to ungrazed plants even after urchins had been removed for $2 \frac{1}{2} \mathrm{mo}$.

\section{Does grazing by Holopneustes purpurescens result in increased levels of phlorotannins in Ecklonia radiata?}

There was no significant difference in change in phlorotannin levels among treatments for either the autumn or spring experiment (Fig. 8A, B), indicating that grazing by Holopneustes purpurescens does not induce increased levels of phlorotannins in Ecklonia radiata. Moreover, if grazing does result in elevated levels of phlorotannins, then we would predict a negative relationship between changes in phlorotannins and changes in biomass for individual kelps (since changes in the biomass of E. radiata are negatively correlated with the damage done by the sea urchins). Regression analyses of changes in phlorotannin levels vs change in mass showed no such relationship for either spring or autumn $\left(\mathrm{r}^{2}<0.02, \mathrm{p}>0.55\right.$ for both analyses).

\section{DISCUSSION}

\section{Holopneustes purpurescens: a 'mega' mesograzer}

In recent years there has been an attempt to categorize marine herbivores by both taxon and ecological 'type', with a certain amount of concordance between the two. One 'type' includes larger herbivores such as herbivorous fishes, sea urchins, and large gastropods which are not restricted to individual host plants, are relatively large in comparison to most seaweeds, are typically generalist feeders (Hay et al. 1988, Hay 1992, Hay \& Steinberg 1992), and are generally thought to have the greatest ecological and evolutionary effects on seaweeds (Carpenter 1986, Hay \& Steinberg 1992). 
In contrast to these larger grazers is the taxonomically diverse group of smaller herbivores termed 'mesograzers', which include arthropods, polychaetes, and smaller gastropods (Hay et al. 1987. Hay 1992, Brawley 1992). Mesograzers have smaller body sizes, use individual seaweed thalli as habitats, typically consume only part of a seaweed thallus rather than the whole plant, and are thought to have less ecological and evolutionary impact on seaweeds than large mobile herbivores (Hay \& Steinberg 1992). In addition, marine herbivores with specialized diets are often mesograzers (Hay 1992, Hay \& Steinberg 1992).

Holopneustes purpurescens represents a mixture of these 2 different categories of herbivores. The sea urchins are large herbivores ( $\geq 50 \mathrm{~mm}$ test diameter), comparable in size to many other bottom dwelling sea urchins, and can have a significant impact on macroalgae. However, they are relatively sedentary, apparently restricted to moving within and among algal thalli (I never saw an individual moving across the substratum), and like smaller, more typical mesograzers, use their seaweed hosts as food and habitat. The sea urchins have a limited range of host plants and, in this study, were only found on 2 species of algae, Ecklonia radiata and Homoeostrichus sinclairii. Observations of H. purpurescens at other sites near Sydney (pers. obs.) indicate that they can occur on other species of algae (usually other large phaeophytes), but such individuals are generally small (ca $<25 \mathrm{~mm}$ test diameter), as was the case for individuals found on $H$. sinclairii at Cape Banks. Given the animals' size as adults, they are probably ultimately restricted to using only the largest local seaweeds as host plants. These observations are consistent with the notion (Hay \& Steinberg 1992) that the use of plants as habitat as well as for food facilitates restricted host plant range for marine herbivores.

The mesograzer strategy of using seaweeds as both food and habitat by Holopneustes purpurescens has resulted in a foraging behavior very different from that of most other herbivorous sea urchins. Most herbivorous sea urchins typically adopt either a sit and wait foraging strategy, in which they feed primarily on drift algae which washes by, or they actively move about the substratum, grazing on living algae or other organisms (Lawrence \& Sammarco 1982, Harrold \& Pearse 1987). Many species of sea urchins in fact exhibit both kinds of behavior, with temporal shifts between the 2 types of foraging mode resulting from a complex interaction of food availability, abundance of refuges, phylogenetic history, etc. (Harrold \& Reed 1985, Andrew \& Stocker 1986). Most herbivorous sea urchins are also very generalized feeders, unlike $H$. purpurescens.

A variety of other marine herbivores also share the mixture of mesograzer and large herbivore character- istics exhibited by Holopneustes purpurescens. A good example are the so-called 'kelp limpets', which live obligately on the thalli of a number of species of Laminariales (kelps) throughout the world (Branch 1981). Like $H$. purpurescens these limpets can be relatively large, use individual plants as habitats, have restricted (often monospecific) host plant ranges, and can cause significant damage to their host plants (Black 1976). Some kelp limpets also have distinct shell shapes (Black 1976, Branch 1981) which facilitate the use of a kelp thallus as a habitat. The morphology of $H$. purpurescens should also facilitate the use of kelp as a habitat. The animals have very short spines, which presumably allows them to wrap laminae close to the test, minimizing the chance of being dislodged from the kelp.

Some mesograzers, particularly amphipods and other crustaceans, brood their offspring, rather than producing planktonic larvae. Such a life history may facilitate dietary/habitat specialization since producing short-lived or brooded larvae would increase the probability that juveniles recruit into the aduit habitat (Hay \& Steinberg 1992). Interestingly, Holopneustes purpurescens, unlike the majority of regular sea urchins (Emlet et al. 1987), produces a large floating egg (Mortensen 1915) which develops into a shortlived (2 to $4 \mathrm{~d}$ ) lecithotrophic larva (J. Crystal pers. comm.). However, the generalist, bottom dwelling Australian sea urchin Heliocidaris erythrogramma also has a short-lived lecithotrophic larva (Mortensen 1915, Wray \& Raff 1991); thus, any connection between life history and dietary or habitat specialization in these sea urchins is unlikely to be a simple one.

\section{Effects of Holopneustes purpurescens on Ecklonia radiata}

The extent to which mesograzers have significant effects on macroalgae - particularly non-epiphytes is the subject of current debate (Bell 1991, Duffy \& Hay 1991 b, Brawley 1992, Poore 1994). One common view is that mesograzers generally have little direct effect on larger seaweeds, in contrast to large grazers such as sea urchins which can clear entire kelp forests. The effect of Holopneustes purpuescens on Ecklonia radiata is intermediate between these extremes. The sea urchins consume the kelp, removing significant amounts of biomass, and higher densities of large individuals can kill kelps. These effects vary predictably with season, size and density of the sea urchins, and length of time the sea urchins are on a kelp. However, unlike grazing by many other temperate sea urchins (reviews by Schiel \& Foster 1986, Harrold \& Pearse 1987), consumption of E. radiata by $H$. purpurescens 
does not usually result in the death of the kelp. This non-lethal effect is due both to the rapid growth of $E$. radiata in spring and to the sea urchin's pattern of feeding on the kelp - H. purpurescens consumes secondary laminae preferentially to the more valuable (to the kelp) primary laminae or meristem. Johnson \& Mann (1988) describe a similar pattern for consumption of kelp by herbivorous gastropods.

The lack of an effect of Holopneustes purpurescens on Ecklonia radiata in autumn has 2 likely explanations. Firstly, in autumn and early winter E. radiata loses biomass naturally at a rapid rate (Novaczek 1984a, b, Larkum 1986, this study), and the sea urchins may simply be feeding on tissue that is sloughing from the plant, which would be lost even in the absence of grazing. Alternatively, feeding rates of $H$. purpurescens may be significantly lower in autumn/ winter than in spring due to lower water temperatures.

A surprising aspect of the interaction was that although the magnitude and seasonal pattern of elongation by Ecklonia radiata observed in this study was comparable to previous research (Kirkman 1984, Novaczek 1984a, b, Larkum 1986), Holopneustes purpurescens had no apparent effect on elongation rates of E. radiata. Even though the sea urchins removed as much as $50 \%$ of the biomass from some thalli in spring, the kelp continued to elongate at a seasonally dependent rate, even if consumption ultimately resulted in death (as in the $2 \mathrm{~L}$ treatment). Loss of substantial amounts of photosynthetic tissue did not result in slowed rates of elongation, indicating that growth (as measured by elongation) is not a simple function of the biomass present at any given time. The rapid growth of E. radiata in spring is probably due in part to stored reserves, as for other kelps (Chapman \& Craigie 1977).

Compensatory growth in response to consumption is known for a number of terrestrial plants (McNaughton 1983), but did not occur in Ecklonia radiata in this study. This lack of a compensatory growth response, and the fact that even short bursts (e.g. 2 to $4 \mathrm{wk}$ ) of grazing by Holopneustes purpurescens can have significant and lasting effects on E. radiata, is important to their interaction because it suggests that even an intermittent regime of grazing by the sea urchins will still probably have an impact on the kelp.

\section{Effects of phlorotannins on the interaction}

The role of algal secondary metabolites as defenses against marine herbivores has received considerable recent attention (reviews by Hay \& Fenical 1988, Hay \& Steinberg 1992). In temperate brown algae, the major putative chemical defenses are phlorotannins (Ragan \& Glombitza 1986). Although species of the genus Ecklonia, and E. radiata in particular, typically contain high levels of phlorotannins (Steinberg 1989, Tugwell \& Branch 1989, Steinberg \& van Altena 1992), variation in phlorotannin levels in laminae of E. radiata was not correlated with variation in consumption rates by Holopneustes purpurescens. Tolerance to phlorotannins occurs in other large invertebrate herbivores in temperate Australasia (Steinberg \& van Altena 1992), and mesograzers are also often resistant to a host's secondary metabolites (Hay et al. 1987, 1988, Hay 1992). In this respect the characteristics of mesograzers and large herbivores in Australia appear to have converged.

Induction of increased levels of phlorotannins following grazing or artificial damage has been shown for Fucus spp. from North America (Van Alstyne 1988, Yates \& Peckol 1993). However, artificial clipping of laminae of Ecklonia radiata and Sargassum vestitum (Steinberg 1994) did not induce elevated levels of phlorotannins, and the results presented here confirm these earlier observations for a natural herbivore of $E$. radiata for a range of levels of damage (e.g. Fig. 8). This result may be explained by a lack of effect of phlorotannins on Hopolneustes purpurescens. However, other herbivores feed on E. radiata (Schiel 1982, Andrew \& Jones 1990) and induction of phlorotannins could potentially be beneficial as a general response to damage if other herbivores or natural enemies (e.g. pathogens) are deterred by E. radiata phlorotannins. In the only other study to date on induction of phlorotannins in kelps (Order Laminariales), Pfister (1992) found no evidence of induction in Alaria nana.

Acknowledgements. This research was done while I was a Queen Elizabeth II Fellow at the University of Sydney and was also supported by an Australian Research Council grant to lan van Altena and Peter Steinberg. I thank K. Groome, E. O'Brien, and D. van Dyke for their help with field work, J. Estes, R. de Nys, and A. G. Poore for their comments on the manuscript, and M. Byrne and J. Crystal for their help with the taxonomy and larval biology (respectively) of Holopneustes.

\section{LITERATURE CITED}

Andrew NL (1988) Ecological aspects of the common sea urchin, Evechinus chloroticus, in northern New Zealand: a review. NZ J mar Freshwat Res 22:415-426

Andrew NL (1993) Spatial heterogeneity, sea urchin grazing and habitat structure on reefs in temperate Australia. Ecology 74:292-302

Andrew NL, Jones GP (1990) Patch formation by herbivorous fish in a temperate Australian kelp forest. Oecologia 85: $57-68$

Andrew NL, Stocker LJ (1986) Dispersion and phagokinesis in the echinoid Evechinus chloroticus. J exp mar Biol Ecol 100:11-23

Bell SS (1991) Amphipods as insect equivalents? An alternative view. Ecology 72:350-354 
Black R (1976) The effects of grazing by the limpet Acmaea insessa, on the kelp Egregia laevigata, in the intertidal zone. Ecology 57:265-277

Branch GM (1981) The biology of limpets: physical factors, energy flow, and ecological interactions. Oceanogr mar Brol A Rev 19:235-380

Brawley SH (1992) Mesoherbivores. In: John DM, Hawkins SJ, Price JH (eds) Plant-animal interactions in the marine benthos. Clarendon Press, Oxford, p 235-263

Carpenter R (1986) Partitioning herbivory and its effects on coral reef algal communities. Ecol Monogr 56:345-63

Chapman ARO, Craigie JS (1977) Seasonal growth in Laminaria lonigicruis: relations with dissolved inorganic nutrients and internal reserves of nitrogen. Mar Biol 40: $197-205$

Dakin WJ (1980) Australian seashores. Angus and Robertson, Sydney

Duffy JE, Hay ME (1991a) Food and shelter as determinants of food cholce by an herbivorous marine amphipod. Ecology 72:1286-1298

Duffy JE, Hay ME (1991b) Amphipods are not all created equal: a reply to Bell. Ecology 72:354-358

Emlet RB, McEdward LR, Strathman RR (1987) Echinoderm larval ecology viewed from the egg. Echinoderm Stud 2: $55-136$

Fauchald K, Jumars PA (1979) The diet of worms: a study of polychaete feeding guilds. Oceanogr mar Biol A Rev 17 : $193-284$

Fletcher WJ (1987) Interactions among subtidal Australian sea urchins, gastropods, and algae: effects of experimental removals. Ecol Monogr 57:89-109

Hacker SD, Steneck RS (1990) Habitat architecture and the abundance and body-size-dependent habitat selection of a phytal amphipod. Ecology 71:2269-2285

Harrold C, Pearse JS (1987) The ecological role of echinoderms in kelp forests. Echinoderm Stud 2:137-233

Harrold C, Reed DC (1985) Food availability, sea urchin grazing, and kelp forest community structure. Ecology 66 $1160-1169$

Hawkins SJ, Hartnoll RG (1983) Grazing of intertidal algae by marine invertebrates. Oceanogr mar Biol A Rev 21 $195-282$

Hay ME (1992) The role of seaweed chemical defenses in the evolution of feeding specialization and in the mediation of complex interactions. In: Paul VJ (ed) Ecological roles for marine secondary metabolites. Comstock Publications, Cornell, NY, p 93-118

Hay ME, Duffy JE, Pfister CA, Fenical W (1987) Chemical defense against different marine herbivores: are amphipods insect equivalents? Ecology 68:1567-80

Hay ME, Fenical W (1988) Marine plant herbivore interactions: the ecology of chemical defense. A Rev Ecol Syst 1.9: $111-145$

Hay ME, Renaud PE, Fenical W (1988) Large mobile versus small sedentary herbivores and their resistance to seaweed chemical defenses. Oecologia 75:246-252

Hay ME, Steinberg PD (1992) The chemical ecology of plantherbivore interactions in marine versus terrestrial conmunities. In: Rosenthal G, Berenbaum $M$ (eds) Herbivores their interactions with secondary plant metabolites, Vol 2 Ecological and evolutionary processes, 2nd edn. Academic Press, New York, p 371-414

John DM, Hawkins SJ, Price JH (eds) (1992) Plant-animal interactions in the marine benthos. Oxford Unversity Press, Oxford

Johnson CR, Mann KH (1988) The importance of plant defence ablities to the structure of subtidal seaweed communities: the kelp Laminaria lonqicruis de la Pylaie survives grazing by the snail Lacuna vincta (Montagu) at high population densities. J exp mar B1ol Ecol 97:231-267

Kurkman H (1984) Standing stock and production of Ecklonia radiata (C. Ag.) J. Agardh. J exp mar Biol Ecol 76:119-130

Larkum AWD (1986) A study of growth and primary production in Ecklonia radiata (C. Ag.) J. Agardh. (Laminariales) at a sheltered site in Port Jackson. New South Wales. $J$ exp mar Biol Ecol 96:177-190

Lawrence JM (1975) On the relationships between martne plants and sea urchins. Oceanogr mar Biol A Rev 13 $213-286$

Lawrence JM, Sammarco PW (1982) Effects of feeding on the environment: Echinoidea. In: Jangoux M, Lawrence $J M$ (ed) Echinoderm nutrition. AA Balkema, Rotterdam, p $409-519$

Lubchenco J, Gaines SD (1981) A unified approach to marine plant-herbivore interactions 1 . Populations and communities. A Rev Ecol Syst 12:405-437

Mann KH (1972) Ecological energetics of the seaweed zone in a marine bay on the Atlantic coast of Canada. II. Productivity of the seaweeds. Mar Biol 14:199-209

Mann KH, Kirkman H (1981) Biomass method for measuring productivity of Ecklonia radiata, with the potential for adaptation to other large brown algae. Aust J mar Freshwat Res 32:297-304

McNaughton SJ (1983) Compensatory plant growth as a response to grazers. Oikos 40:329-336

Mortensen $T$ (1915) Preliminary notes on the remarkable shortened development of an Australian sea-urchin, Toxocidaris erythrogrammus. Proc Linn Soc NSW 40:203-206

Novaczek I (1984a) Response of Ecklonla radiata (Laminariales) to light at $15^{\circ} \mathrm{C}$ with reference to the field light budget at Goat Island Bay, New Zealand. Mar Biol 80:263-272

Novaczek I (1984b) Development and phenology of Ecklonia radiata at two depths in Goat Island Bay, New Zealand. Mar Biol 81:189-197

Pfister CA (1992) Costs of reproduction in an intertidal kelp: patterns of allocation and life history consequences. Ecology 73:1586-1596

Poore AGB (1994) Selective herbivory by amphipods inhabiting the brown alga Zonaria angustata. Mar Ecol Prog Ser 107:113-122

Ragan MA, Glomibtza KW (1986) Phlorotannins, brown algal polyphenols. Prog Phycol Res 4:129-241

Ragan MA, Jensen A (1977) Quantitative studies on brown algal phenolics. I. Estimation of absolute polyphenol content in Ascophyllum nodosum and Fucus vesiculosus. $\mathrm{J}$ exp mar Biol Ecol 34:245-258

Schiel DR (1982) Selective feeding by the echinoid Evechinus chloroticus, and the removal of plants from subtidal algal stands in northern New Zealand. Oecologia 54:379-388

Schiel DR, Foster MS (1986) The structure of subtidal algal stands in temperate waters. Oceanogr mar Brol A Re? 24: $265-307$

Steinberg PD (1989) Biogeographical variation in brown algal polyphenolics and other secondary metabolites: comparıson between temperate Australasia and North America. Oecologia 78:374-383

Steinberg PD (1994) Lack of short term induction of phlorotannins in the Australian brown algae Sargassum vestitum and Ecklonia radiata. Mar Ecol Prog Ser 121:129-133

Steinberg PD, van Altena I (1992) Tolerance of marine nuvertebrate herbivores to brown algal phlorotannins in temperate Australasia. Ecol Monogr 62:189 222

Tugwell S, Branch GM (1989) Differential polyphenolic distr1bution among tissues in the kelp Ecklonı maxima, Lamı- 
naria pallida and Macrocystis angustifolia in relation to plant-defence theory. J exp mar Biol Ecol 129:219-230

Van Alstyne KL (1988) Herbivore grazing increases polyphenolic defenses in the intertidal brown alga Fucus distichus. Ecology 69:655-663

This article was presented by J. M. Lawrence (Senior Editorial Advisor), Tampa, Florida, USA
Wray GA, Raff RA (1991) The evolution of developmental strategy in marine invertebrates. Trends Ecol Evol 6:45-50 Yates J, Peckol P (1993) Effects of nutrient availability and herbivory on polyphenolics in the seaweed Fucus vesiculosus. Ecology 74:1757-1766

Manuscript first received: November 1, 1994

Revised version accepted: April 19, 1995 